\title{
カーネーションの蕾開花促進法における品種適応性
}

\author{
水口 聡 $*$ a 渡辺 久・川崎哲郎 \\ 愛媛県農業試験場７99-2405＼cjkstart松山市上難波
}

\section{Applicability of Commercial Carnation Cultivars to Bud Anthesis Acceleration (BAA) Method}

\author{
Satoshi Minakuchi*a , Hisashi Watanabe and Tetsuro Kawasaki \\ Ehime Agricultural Experiment Station, Matsuyama, Ehime 799-2405
}

\begin{abstract}
The applicability of commercial carnation cultivars (Dianthus caryophyllus L.) to Bud Anthesis Acceleration (BAA) method was investigated. Six standard type cultivars and five spray type cultivars were placed in BAA solution containing $5 \%$ sucrose, and kept at temperature of $25^{\circ} \mathrm{C}(75 \% \mathrm{RH})$, light intensity of $1 \mathrm{klx}$ and $12 \mathrm{~h}$ photoperiod. Harvesting at the small bud stage promoted calyx splitting and petal wilting in all cultivars. In the range of available bud diameter without causing damage on flower, the BAA treatment shortened the recommended days to shipping in all cultivars. Flower diameter was decreased by the treatment in 'Pleasure' and 'Roland'. Petal color pigmentation was inhibited in 'Opera', 'Riccard' and 'Lavender Tessino'. Vase life was shortened in 'Pleasure', 'Saleya', 'Lavender Tessino' and 'Roland'. Although most of these problems were solved by harvesting at large bud stage, petal color pigmentation in 'Lavender Tessino' and flower diameter and vase life in 'Roland' could not be improved by modification of BAA treatment since these cultivars have a high sugar concentration in the petal. It was concluded that 'Lavender Tessino' and 'Roland' were unsuitable for BAA method.
\end{abstract}

Key Words : bud diameter, flower diameter, harvesting stage, petal color expression, vase life キーワード : 花持ち, 花径, 花色発現, 収穫ステージ, 蕾径

\begin{abstract}
緒 言
カーネーションの需要は 5 月の「母の日」前に急増し市 場価格が高くなるが，「母の日」を過ぎると, 約 8 分の 1 と 大きく下落するため, 開花が間に合わなかった蕾はほとん ど廃棄されて扣り，これらの有効利用技術の開発が求めら れている (Minakuchiら, 2004).

これまでに, 蕾状態で採取後それらを低温で貯蔵し, 出荷前に開花させる手法の検討が数多くなされてきた (Cywińska ら, 1978; Goszczyńska • Rudnicki, 1983; Kofranek ら，1972；小山・宇田，1994a, b; Rudnicki ら，1989).これ らの技術は，「母の日」など目的とする出荷日より早く開花 してしまら蕾をあらかじめ収穫, 低温貯蔵しておき, 出荷 日前に強制開花させるといら出荷調節の考え方に拠ってい る. これに対し, 我々は目的とする出荷日に開花が間に合 わないと思われる蕾を採取し，糖などの栄養を与えるとと もに，光を照射しながら高温環境下に置くことにより蕾の 発育・開花を促進し, 目的とする日に切り花として出荷す
\end{abstract}

2007 年 6 月 3 日 受付. 2007 年 10 月 25 日 受理.

* Corresponding author. E-mail: minakuchi-satoshi@pref.ehime.jp

a 現在 : 愛媛県農林水産部 790-8570 松山市一番町
る「蕾開花促進法 (BAA法)」の有用性を提案した (Minakuchi ら, 2004).

これまでに，ピンク花色のスタンダードタイプ品種 ‘ ラ’については, 次のように詳細な処理条件の検討を行っ ている. 収穫時の蕾ステージは蕾の直径 $1.5 \mathrm{~cm}$ 以上が適し, 処理温度 $20^{\circ} \mathrm{C}, 25^{\circ} \mathrm{C}$ 扎よび $30^{\circ} \mathrm{C}$ では温度が高いほど開花 所要日数は短くなるが, $20^{\circ} \mathrm{C}$ 処理では花の大きさが小さく 花持ちが悪く, $25^{\circ} \mathrm{C}$ 処理でも花持ちが悪化し， $30^{\circ} \mathrm{C}$ 処理 では花弁の色調が大きく変化する（水口ら，2005a）。こ机 に対して，光環境を照度 $1 \mathrm{klx}$ 連続照射から 12 時間日長に することで，開花後の花持ち日数が長くなり通常の切り花 と同等になる（水口ら，2007a）。むた，処理液のスクロー ス濃度を高くすることで，開花時の花が大きくなり花色発 現が良好となる（水口ら，2007b）。このように，品種“ノ ラ’では処理温度と処理液中のスクロース濃度を調節する ことで，さまざまな蕾ステージや目標出荷日までの日数に 対応でき,「母の日」前に高品質切り花を出荷できるように なった。しかし，生産現場では多くの品種が栽培されてお り, BAA 法に適する収穫時の蕾ステージやそのときの切り 花品質は品種ごとに異なると考学なれる，そこで，愛媛県 で栽培されている 11 品種を対象に, 異なる蕾ステージで収 穫し同一条件で BAA 処理した場合の切り花品質を調査す 
るとともに，このときの花弁中の糖質濃度を測定すること で処理液組成の改善策について検討し, 総合的な品種適応 性の評価を行った。

\section{材料および方法}

\section{1. 供試材料}

愛媛県内で栽培されている主な 11 品種を供試した. スタ ンダードタイプ品種として，“オペラ’（ピンク），“デル フィ’(白), ‘プレジャー’ (ブロンズイエロー), ‘リルド’ (赤), ‘サレヤ’ (薄黄に赤の覆輪), ‘ジュディス’（淡いピ ンクにワイン色の覆輪）の 6 品種, スプレータイプ品種と して，“ホワイトバーバラ’(白), ‘ライトピンクバーバラ’ (淡いピンク), ‘ラベンダーテッシノ’（ライラックに白の 覆輪), ‘ローランド’ (紫), ‘マエストロ’（オレンジ色に 紫赤色の条覆輪）の5品種をそれぞれ供試した． 2000 年 6 月に愛媛県伊予郡松前町の温室に定植し, 栽培管理などは 愛媛県の標準とした(愛媛県農林水産部技術指導課, 1999). 蕾の生育速度や切り花品質を比較するための対照として, 温室内でそのまま生育させ慣行の収穫期に收檴したものを 調查し通常收穫区とした.

\section{2. 収穫時の蕾ステージ}

第 1 図に採取時と蕾開花促進処理後のカーネーションの 様子を示す。まず，蕾ステージの限界を明らかにするため に，幅広い蕾ステージで 30 本程度ずつ收穫し，BAA 処理 による障害発生を調査した。スタンダードタイプ品種では 蕾の直径が $12 \mathrm{~mm}$ から $20 \mathrm{~mm}$, スプレータイプ品種では頂 花蕾摘除直後から第 1 花 (1 茎中で最子生育の進んだ花蕾) の蕾径が $15 \mathrm{~mm}$ までとした．次に，この結果より障害が発 生しないことが判明した範囲の蕾ステージで，蕾径に基づ き大・中・小 $(\mathrm{L} ・ \mathrm{M} ・ \mathrm{~S})$ の 3 段階に分類した。 この蕾ス テージごとに 10 本ずつ收檴し，BAA 処理による開花時の 切り花品質を調查した. BAA 区に抢ける収穫時の蕾径を説 明変数 $(\mathrm{X})$, このときの出荷所要日数を目的変数 $(\mathrm{Y})$ と して回帰式を作成し，収穫時の蕾径による出荷所要日数の 予測を試久た。

\section{BAA 処理条件}

収穫した蕾切り花を切り花長 $75 \mathrm{~cm}$ に切り揃えて下葉を

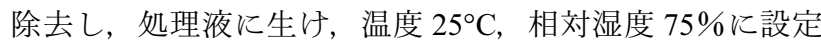
した恒温恒湿器（TBR-2.5WOSX，タバイエスペック）内に 設置した．光環境は品種 ‘ノラ’による検討では連続照射
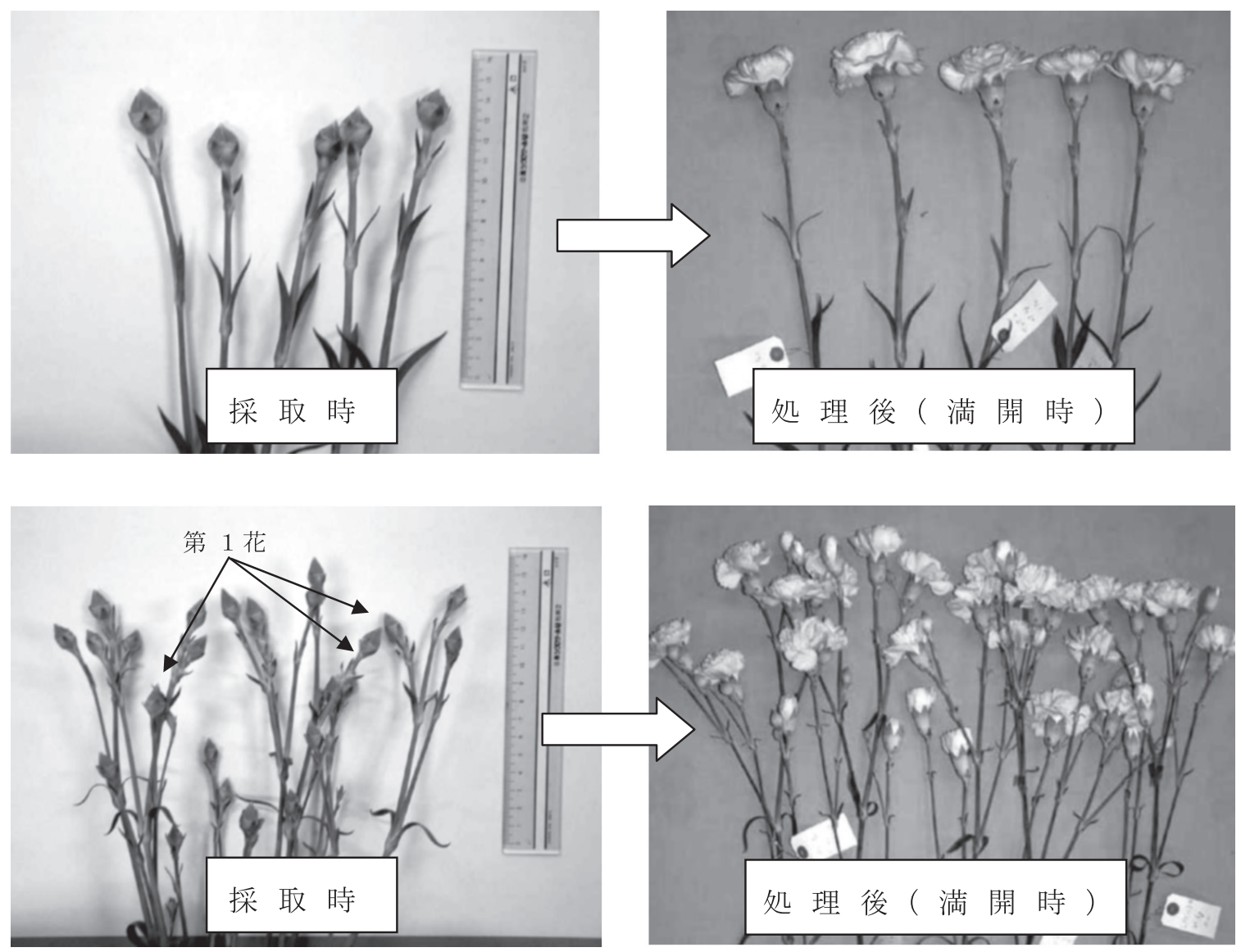

第 1 図 採取時と蕾開花促進処理後のカーネーション

上：スタンダードタイプ'サレヤ’

下：スプレータイプ'ライトピンクバーバラ’

(スプレータイプの第 1 花 : 1 茎中で最も生育の進んだ花蕾) 
より 12 時間日長の方が開花後の花持ちが良好になる(水口 ら, 2007a) ことから, 蛍光灯 (40W, FL40SS-D/37, SANYO) を用いて照度 $1 \mathrm{klx}$ とし，プログラムタイマー（KS-1500， アズワン）を用いて 12 時間日長に調節した。

出荷前にチ才硫酸銀錯塩（STS）による前処理を行らの であれば, BAA 処理液には硝酸銀は必要ないことが明らか となっている（水口ら，2005b）ため， 200 ppm の 8- ハイ ドロキシキノリン硫酸塩（8-HQS）および5\%のスクロー スを蒸留水に溶解した処理液を用いた. 処理期間中, 処理 液の更新は行わず, 切り口が処理液に $3 \mathrm{~cm}$ 程度浸かった状 態を維持するために補充するのみとした，このとき，処理 期間中に処理液の濁りは見られず，屈折糖度計で糖濃度を 確認したところ, 数值に変動は認められなかった. 処理は 出荷適期に達するまで継続し, これらを蕾開花促進区 (BAA 区) とした.

\section{4. 切り花品質評価}

スタンダードタイプでは外側の花弁が $1 〜 2$ 枚が開いた 時点, スプレータイプでは第1花の花弁が同様の状態になっ た時点を出荷適期とみなした. BAA 区では収穫時から出荷 適期に達するまでの日数を出荷所要日数とした，通常收穫 区では蕾の直径を測定しラベルを付け，そのまま八ウス内 で生育させた場合の出荷適期になるまでの日数を出荷所要 日数とした.

いずれの区も, 出荷適期に達した時点で, $0.5 \mathrm{mM}$ の STS で 6 時間前処理を行った後, 水道水に生け, 温度 $25^{\circ} \mathrm{C}$, 相 対湿度 75\%，12 時間日長（照度 $1 \mathrm{klx}$ ）条件下で放置した。 外側の花弁が水平に展開した時点を満開とし, 満開時の花 径および花弁色調を測定した. スプレータイプの品種につ いては第 1 花を調査対象とした。花径は，ノギスを用いて 花の直径を測定した. 花弁色調は, ミノルタ社の色彩計 Minolta Chroma Meter CR-200b を用いて, 十分に展開した外 側花弁の中央部の明度 $\left(\mathrm{L}^{*}\right)$ 扎よびクロマティクネス指数 $\left(\mathrm{a}^{*}\right.$ および $\left.\mathrm{b}^{*}\right)$ を測定した。 測定值から $\mathrm{C}^{*}=\left(\mathrm{a}^{* 2}+\mathrm{b}^{* 2}\right)^{1 / 2}$ の式により彩度を, $\mathrm{h}^{\circ}=\left(\operatorname{ATAN}\left(\mathrm{b}^{*} / \mathrm{a}^{*}\right) / 6.2832\right) \times 360$ の式に より色相角度をそれぞれ算出した（McGuire, 1992）。覆輪 の品種のらち花弁中央部に複数の色が存在する ‘サレヤ’, ‘ジュディス’执よび'マエストロ’については調査対象外 とした. 生け水の水道水は 2 から 3 日ごとに更新し, 前処 理直後から花弁が萎れ始めるまでの日数を花持ち日数とし た. 1 茎に複数の花蕾のあるスプレータイプの花持ち日数 は，過半数の花蕾で観賞価值が消失した時点までの日数と した。

\section{5. 花弁中糖質濃度の測定}

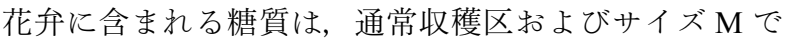
処理したBAA 区について，満開時に分析を行った．分析 は3 反復とした.

糖質の抽出は以下の手順で行った. 花弁を $1 \mathrm{~g}$ ずつ採取

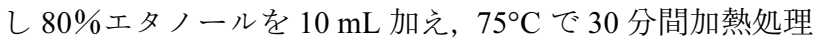
した. 冷却後, 内部標準として $2.5 \%$ マンニトール水溶液を
$100 \mu \mathrm{L}$ 加えホモジナイズし， 3,000 rpm で 10 分間遠心分離 後，上澄みを回収した．残さに $80 \%$ エタノールを $5 \mathrm{~mL}$ 加 え再抽出した。再抽出は 2 回くり返した。遠心エバポレー ターを用いて回収した上澄みを減圧乾固させ, $1 \mathrm{~mL}$ の蒸留 水で再び溶解し，抽出サンプルとした．抽出サンプルを Sep-Pak プラス C18 に通し,さらに $2 \mathrm{~mL}$ の蒸留水で洗った 後, $0.45 \mu \mathrm{m}$ のフィルターに通し, 高速液体クロマトグラ フィー（HPLC）分析に供した.

HPLC 分析カラムには昭和電工社製の Shodex SUGAR SP0810を用いた．溶離液には $0.45 \mu \mathrm{m}$ の Membrane filter で ろ過した蒸留水を用いた，カラムの温度は $80^{\circ} \mathrm{C}$, 流速は $0.8 \mathrm{~mL} \cdot \mathrm{min}^{-1}$ とした. 検出器には示差屈折率検出器を用い た. スクロース，フルクトース，グルコース，ピニトール およびミオイノシトールの濃度はマンニトールを用いた内 部標準法にて算出した.

\section{結 果}

\section{1. 障害発生の生じない収穫時の蕾径}

第 1 表に収穫時の蕾径と BAA 処理による障害発生の結 果を示す。いずれの品種でも，がく割れや花弁の萎调等の 障害発生が認められ，採取時の蕾径が小さいほど障害発生 率が高くなった。これらの障害発生を回避するためには, ある程度生育した蕾段階での収穫が有効であった。すなわ ち, ‘プレジャー’ では蕾径 $18 \mathrm{~mm}$ 以上, ‘デルフィ’ では $16 \mathrm{~mm}$ 以上, ‘リカルド’ と“ジュディス’では $15 \mathrm{~mm}$ 以 上， ‘才ペラ’ では $14 \mathrm{~mm}$ 以上，“ホワイトバーバラ’ では $11 \mathrm{~mm}$ 以上, ‘ライトピンクバーバラ’ では $10 \mathrm{~mm}$ 以上, ‘ラベンダーテッシノ’と“ローランド’では $8 \mathrm{~mm}$ 以上の 蕾ステージで収穫することで，障害を回避できることが明 らかとなった。一方，“マエストロ’では $10 \mathrm{~mm}$ 以上で 4 \%, “サレヤ’では $16 \mathrm{~mm}$ 以上で $10 \%$ のがく割れが発生した.

\section{2. 収穫時の蕾径が出荷所要日数や切り花品質に及ぼす 影響}

障害発生の生じない蕾段階に抢ける収穫時の蕾径，出荷 所要日数拈よび切り花品質の結果を第 2 表に示す.

BAA 処理において, スタンダードタイプ品種の出荷所要 日数は 7.2 日から 14.7 日，スプレータイプ品種では 5.0 日 から 13.4 日で, 採取時の蕾が大きいほど出荷所要日数が短 くなった.

花の大きさは, ‘オペラ’, ‘デルフィ’, ‘サレヤ’, ‘ジュ ディス’，‘ラベンダーテッシノ’扎よび'マエストロ’で は, いずれの蕾径で処理を行っても満開時の花径は通常収 穫区と有意差が認められなかった。“リカルド，“ホワイト バーバラ’拈よび‘ライトピンクバーバラ’ではBAA 区 の方が花径が大きくなる傾向にあり, ‘プレジャー’ではサ イズ S で処理した場合にの久有意に花径が小さくなった. “ローランド”ではいずれの蕾径で処理しても通常收穫区よ り花径が有意に小さくなった.

花弁色調は，“デルフィ’打よび‘プレジャ一’では，す 
第 1 表 収穫時の蕾径と障害発生の関係

\begin{tabular}{|c|c|c|c|}
\hline 品種 ${ }^{\mathrm{Z}}$ & 収穫時蕾径（mm） & 障害発生率（\%） & 主な症状 \\
\hline \multirow{2}{*}{ オペラ } & $12 \sim 13$ & 50 & \multirow{2}{*}{ がく割れ } \\
\hline & $14 \sim 19$ & 0 & \\
\hline \multirow{2}{*}{ デルフィ } & $12 \sim 15$ & 20 & \multirow{2}{*}{ がく・上位葉の黄化 } \\
\hline & $16 \sim 18$ & 0 & \\
\hline \multirow{2}{*}{ プレジャー } & $14 \sim 17$ & 67 & \multirow{2}{*}{ がく割れ，花弁萎调 } \\
\hline & $18 \sim 19$ & 0 & \\
\hline \multirow{2}{*}{ リカルド } & $12 \sim 14$ & 20 & \multirow{2}{*}{ 花弁萎调 } \\
\hline & $15 \sim 19$ & 0 & \\
\hline \multirow{2}{*}{ サレヤ } & $13 \sim 15$ & 80 & \multirow{2}{*}{$\begin{array}{l}\text { がく割れ，花弁萎调 } \\
\text { がく割れ }\end{array}$} \\
\hline & $16 \sim 18$ & 10 & \\
\hline \multirow{2}{*}{ ジュディス } & $12 \sim 14$ & 43 & \multirow{2}{*}{ 花弁萎调，がく乾燥 } \\
\hline & $15 \sim 19$ & 0 & \\
\hline \multirow{2}{*}{ ホワイトバーバラ } & $4 \sim 10$ & 100 & \multirow{2}{*}{ がく割れ，花弁萎调 } \\
\hline & $11 \sim 13$ & 0 & \\
\hline \multirow{2}{*}{ ライトピンクバーバラ } & $4 \sim 9$ & 63 & \multirow{2}{*}{ がく割れ，花弁萎调 } \\
\hline & $10 \sim 13$ & 0 & \\
\hline \multirow{2}{*}{ ラベンダーテッシノ } & $5 \sim 7$ & 83 & \multirow{2}{*}{ 花弁萎凋 } \\
\hline & $8 \sim 12$ & 0 & \\
\hline \multirow{2}{*}{ ローランド } & $6 \sim 7$ & 14 & \multirow{2}{*}{ 花弁萎凋 } \\
\hline & $8 \sim 10$ & 0 & \\
\hline \multirow{2}{*}{ マエストロ } & $4 \sim 9$ & 80 & \multirow{2}{*}{$\begin{array}{l}\text { がく黄化, 花弁萎调 } \\
\text { がく割机 }\end{array}$} \\
\hline & $10 \sim 15$ & 4 & \\
\hline
\end{tabular}

${ }^{\mathrm{z}}$ 上 6 品種はスタンダードタイプ, 下 5 品種はスプレータイプ スプレータイプの蕾径は第 1 花の測定值

ベての BAA 区で花弁の明度，彩度，色相角度ともに通常 收穫区と同等であった。 ‘ホワイトバーバラ’では，すべて のBAA 区で明度，彩度ともに通常収穫区と同等で，サイ ズ L 收穫での久色相角度に有意差が認められたが，可視的 には識別できない程度であった。‘ライトピンクバーバラ’ ではすべての BAA 区で彩度が通常収穫区より有意に大き くなり，花色発現が促進された. ‘ローランド”ではBAA 区の方が明度が小さく彩度と色相角度が大きくなる傾向に あったが，可視的には識別できない程度であった。“才ぺ ラ’ ではすべての BAA 区で明度が有意に大きく, ‘リカル ド’および ‘ラベンダーテッシノ’では明度が大きくなる だけでなく彩度が小さくなり，花色発現が抑制された。

花持ち日数はすべての試験区で 11 日以上を示した. BAA 区の花持ちを通常収穫区と比較すると, ‘デルフィ’, ‘ジュ ディス’，“ホワイトバーバラ’では，すべての BAA区で 通常收穫区と有意差がなかった。 ‘ライトピンクバーバラ’ ではすべてのBAA 区で通常収穫区より花持ちが有意に長 くなった. ‘オペラ’, “リカルド”扎よび“マエストロ’で はサイズ Lで処理すると通常収穫区より花持ちが有意に長 くなった. ‘プレジャ一’，“サレヤ’执よび‘ラベンダー テッシノ’ではサイズ $\mathrm{S}$ で処理する場合にのみ通常収穫区

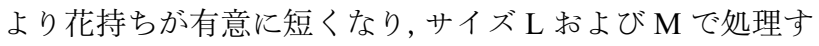
ると通常収穫区と同等となった。“ローランド’ではすべて
のBAA 区で花持ちが短くなる傾向にあった。

BAA 区に打双隻時の蕾径を説明変数（X），このと きの出荷所要日数を目的变数（Y）とした場合の回帰分析 結果を第 3 表に示す.

収穫時の蕾径と出荷所要日数には高い相関が認められ た。 得られた予測式を用いて通常収穫区の調査開始時と同 じ蕾径から BAA 処理区の出荷所要日数を予測し，通常収 穫区の出荷所要日数との差を算出したところ, 出荷所要日 数が 5.7 日〜 10.9 日も短縮できることが明らかとなった.

\section{BAA 処理が花弁中糖質濃度に及ぼす影響}

満開時の花弁中糖質濃度の結果を第 4 表に示す。 HPLC 分析により，スクロース，グルコース，フルクトース，ピ ニトールおよびミオイノシトールが花弁中に検出された. いずれの品種, 試験区でも花弁中のミオイノシトール濃度 はわずかであった。 ‘デルフィ’，“サレヤ’抽よ゙‘ジュ ディス’では，BAA 区と通常収穫区の間で各糖質濃度に有 意な差異は認められなかった。 ‘ラベンダーテッシノ’，“マ エストロ’抽び‘ーランド’では，BAA 区の方がフル クトースとグルコース濃度が有意に高くなった。逆に・リ カルドでは BAA 区の方がフルクトースとグルコース濃 度が有意に低くなった。 
第 2 表 収穫時の蕾径が出荷所要日数および切り花品質に及ぼす影響

\begin{tabular}{|c|c|c|c|c|c|c|c|c|}
\hline \multirow{2}{*}{ 品種名 ${ }^{z}$} & \multirow{2}{*}{$\begin{array}{l}\text { 収穫時の } \\
\text { 蕾ステージ }\end{array}$} & \multirow{2}{*}{$\begin{array}{l}\text { 蕾径 } \\
(\mathrm{mm})\end{array}$} & \multirow{2}{*}{$\begin{array}{c}\text { 出荷所要日数 } \\
\text { (日) }\end{array}$} & \multirow{2}{*}{$\begin{array}{c}\text { 満開時花径 } \\
(\mathrm{mm})\end{array}$} & \multicolumn{3}{|c|}{ 花弁色調 ${ }^{y}$} & \multirow{2}{*}{$\begin{array}{l}\text { 花持ち日数 } \\
\text { (日) }\end{array}$} \\
\hline & & & & & 明度（L*） & 彩度 $\left(\mathrm{C}^{*}\right)$ & 色相角度 $\left(h^{\circ}\right)$ & \\
\hline \multirow{4}{*}{$\begin{array}{l}\text { オペラ } \\
(\text { ピンク })\end{array}$} & $\mathrm{L}$ & 20.8 & $7.4 c^{x}$ & 82.1 & $89.8 \mathrm{a}$ & 7.1 & 29.6 & $16.0 \mathrm{a}$ \\
\hline & M & 18.5 & $10.2 \mathrm{~b}$ & 80.3 & $89.0 \mathrm{a}$ & 7.4 & 32.7 & $18.0 \mathrm{a}$ \\
\hline & S & 14.8 & $14.7 \mathrm{a}$ & 80.4 & $89.4 \mathrm{a}$ & 7.7 & 19.7 & $13.0 \mathrm{~b}$ \\
\hline & 通常収穫 ${ }^{w}$ & 19.6 & $16.0-$ & 84.1 & $86.5 \mathrm{~b}$ & 9.0 & 19.2 & $12.8 \mathrm{~b}$ \\
\hline \multirow{4}{*}{$\begin{array}{l}\text { デルフィ } \\
\text { (白) }\end{array}$} & $\mathrm{L}$ & 18.3 & $8.3 \mathrm{~b}$ & 79.0 & 95.0 & 7.3 & 104.3 & 21.2 \\
\hline & M & 17.3 & $8.3 \mathrm{~b}$ & 78.9 & 95.6 & 6.9 & 103.5 & 21.5 \\
\hline & $\mathrm{S}$ & 15.6 & $11.0 \mathrm{a}$ & 78.7 & 95.4 & 7.3 & 103.5 & 21.0 \\
\hline & 通常収穫 & 16.4 & $16.6-$ & 86.5 & 95.3 & 8.2 & 105.7 & 20.0 \\
\hline \multirow{4}{*}{$\begin{array}{c}\text { プレジャー } \\
(\text { ブロンズイエロー) }\end{array}$} & $\mathrm{L}$ & 19.4 & $7.2 \mathrm{c}$ & $84.2 \mathrm{a}$ & 93.4 & 32.6 & 105.7 & $20.4 \mathrm{a}$ \\
\hline & M & 18.4 & $9.0 \mathrm{~b}$ & $81.7 \mathrm{a}$ & 93.3 & 32.7 & 105.5 & $20.8 \mathrm{a}$ \\
\hline & $\mathrm{S}$ & 15.2 & $13.7 \mathrm{a}$ & $78.2 \mathrm{~b}$ & 93.6 & 31.2 & 106.1 & $17.4 \mathrm{~b}$ \\
\hline & 通常収穫 & 16.2 & $20.8-$ & $84.2 \mathrm{a}$ & 93.3 & 32.8 & 105.5 & $22.2 \mathrm{a}$ \\
\hline \multirow{4}{*}{$\begin{array}{l}\text { リカルド } \\
\text { (赤) }\end{array}$} & $\mathrm{L}$ & 17.7 & $8.8 \mathrm{~b}$ & $84.7 \mathrm{a}$ & $50.7 \mathrm{a}$ & $51.8 \mathrm{~b}$ & 22.5 & $19.8 \mathrm{a}$ \\
\hline & M & 17.2 & $11.0 \mathrm{a}$ & $85.0 \mathrm{a}$ & $50.7 \mathrm{a}$ & $53.9 \mathrm{ab}$ & 23.3 & $16.8 \mathrm{c}$ \\
\hline & $\mathrm{S}$ & 15.1 & $10.8 \mathrm{a}$ & $79.2 \mathrm{ab}$ & $49.6 \mathrm{ab}$ & $51.3 \mathrm{~b}$ & 22.4 & $19.6 \mathrm{ab}$ \\
\hline & 通常収穫 & 17.4 & $17.0-$ & $78.7 \mathrm{~b}$ & $46.9 \mathrm{~b}$ & $58.1 \mathrm{a}$ & 28.8 & $17.2 \mathrm{bc}$ \\
\hline \multirow{4}{*}{$\begin{array}{c}\text { サレヤ } \\
\text { (薄黄・赤の覆輪) }\end{array}$} & $\mathrm{L}$ & 18.1 & $7.5 \mathrm{c}$ & 78.2 & - & - & - & $19.2 \mathrm{ab}$ \\
\hline & M & 17.8 & $8.9 \mathrm{~b}$ & 79.3 & - & - & - & $19.2 \mathrm{ab}$ \\
\hline & S & 16.2 & $12.0 \mathrm{a}$ & 81.4 & - & - & - & $17.2 \mathrm{~b}$ \\
\hline & 通常収穫 & 17.2 & $18.6-$ & 84.1 & - & - & - & $21.5 \mathrm{a}$ \\
\hline \multirow{4}{*}{$\begin{array}{c}\text { ジュディス } \\
(\text { 淡ピンク・ } \\
\text { ワインの覆輪） }\end{array}$} & $\mathrm{L}$ & 19.3 & $7.6 \mathrm{c}$ & 80.3 & - & - & - & 17.8 \\
\hline & M & 17.9 & $9.5 \mathrm{~b}$ & 79.5 & - & - & - & 18.0 \\
\hline & $\mathrm{S}$ & 15.0 & $12.4 \mathrm{a}$ & 79.4 & - & - & - & 17.6 \\
\hline & 通常収穫 & 18.2 & $17.8-$ & 81.7 & - & - & - & 20.2 \\
\hline \multirow{4}{*}{$\begin{array}{c}\text { ホワイトバーバラ } \\
\text { (白) }\end{array}$} & $\mathrm{L}$ & 13.0 & $5.0 \mathrm{~b}$ & $56.0 \mathrm{a}$ & 95.1 & 8.3 & $102.5 \mathrm{a}$ & 14.0 \\
\hline & M & 12.4 & $7.2 \mathrm{~b}$ & $54.5 \mathrm{ab}$ & 95.2 & 8.6 & $100.7 \mathrm{ab}$ & 14.2 \\
\hline & $\mathrm{S}$ & 11.3 & $11.0 \mathrm{a}$ & $57.1 \mathrm{a}$ & 95.5 & 7.4 & $99.1 \mathrm{~b}$ & 15.4 \\
\hline & 通常収穫 & 11.6 & $16.4-$ & $51.8 \mathrm{~b}$ & 95.2 & 7.0 & $99.8 \mathrm{~b}$ & 14.4 \\
\hline \multirow{4}{*}{$\begin{array}{c}\text { ライトピンクバーバラ } \\
\text { (淡いピンク) }\end{array}$} & $\mathrm{L}$ & 12.9 & $8.6 \mathrm{~b}$ & $60.6 \mathrm{a}$ & 85.9 & $16.9 \mathrm{a}$ & 11.6 & $13.0 \mathrm{a}$ \\
\hline & M & 12.2 & $8.8 \mathrm{~b}$ & $59.0 \mathrm{a}$ & 85.0 & $18.1 \mathrm{a}$ & 11.6 & $13.2 \mathrm{a}$ \\
\hline & $\mathrm{S}$ & 11.1 & $11.7 \mathrm{a}$ & $57.0 \mathrm{a}$ & 85.8 & $17.0 \mathrm{a}$ & 13.1 & $14.0 \mathrm{a}$ \\
\hline & 通常収穫 & 12.4 & $16.2-$ & $52.7 \mathrm{~b}$ & 85.6 & $13.7 \mathrm{~b}$ & 15.3 & $11.2 \mathrm{~b}$ \\
\hline \multirow{4}{*}{$\begin{array}{c}\text { ラベンダーテッシノ } \\
(\text { (ライラック・ } \\
\text { 白の覆輪 })\end{array}$} & $\mathrm{L}$ & 11.4 & $5.8 \mathrm{c}$ & 57.3 & $82.2 \mathrm{a}$ & $18.5 \mathrm{~b}$ & $355.4 \mathrm{a}$ & $15.3 \mathrm{a}$ \\
\hline & M & 10.4 & $8.8 \mathrm{~b}$ & 55.8 & $83.2 \mathrm{a}$ & $16.3 \mathrm{~b}$ & $353.7 \mathrm{ab}$ & $16.4 \mathrm{a}$ \\
\hline & $\mathrm{S}$ & 8.4 & $13.4 \mathrm{a}$ & 54.6 & $83.8 \mathrm{a}$ & $16.4 \mathrm{~b}$ & $352.7 \mathrm{~b}$ & $11.2 \mathrm{~b}$ \\
\hline & 通常収穫 & 11.8 & $10.6-$ & 54.5 & $78.6 \mathrm{~b}$ & $23.9 \mathrm{a}$ & $347.6 \mathrm{c}$ & $14.4 \mathrm{a}$ \\
\hline \multirow{4}{*}{$\begin{array}{c}\text { ローランド } \\
\text { (紫) }\end{array}$} & $\mathrm{L}$ & 10.5 & $6.2 \mathrm{c}$ & $43.1 \mathrm{~b}$ & $58.3 \mathrm{~b}$ & $36.1 \mathrm{ab}$ & $345.1 \mathrm{a}$ & $14.3 \mathrm{~b}$ \\
\hline & M & 9.9 & $8.3 \mathrm{~b}$ & $45.0 \mathrm{~b}$ & $57.0 \mathrm{~b}$ & $41.2 \mathrm{a}$ & $345.0 \mathrm{a}$ & $12.8 \mathrm{~b}$ \\
\hline & S & 8.5 & $10.7 \mathrm{a}$ & $43.9 \mathrm{~b}$ & $62.0 \mathrm{ab}$ & $35.7 \mathrm{ab}$ & $344.0 \mathrm{a}$ & $15.0 \mathrm{ab}$ \\
\hline & 通常収穫 & 10.2 & $15.4-$ & $51.1 \mathrm{a}$ & $65.5 \mathrm{a}$ & $31.0 \mathrm{~b}$ & $337.2 \mathrm{~b}$ & $17.0 \mathrm{a}$ \\
\hline \multirow{4}{*}{$\begin{array}{c}\text { マエストロ } \\
(\text { オレンジ・ } \\
\text { 紫赤の条覆輪) }\end{array}$} & $\mathrm{L}$ & 14.2 & $6.9 \mathrm{~b}$ & $61.6 \mathrm{a}$ & - & - & - & $14.3 \mathrm{a}$ \\
\hline & M & 13.4 & $7.6 \mathrm{~b}$ & $60.7 \mathrm{a}$ & - & - & - & $14.3 \mathrm{a}$ \\
\hline & S & 10.8 & $9.9 \mathrm{a}$ & $56.8 \mathrm{~b}$ & - & - & - & $12.0 \mathrm{ab}$ \\
\hline & 通常収穫 & 14.4 & $17.6-$ & $58.3 \mathrm{ab}$ & - & - & - & $11.0 \mathrm{~b}$ \\
\hline
\end{tabular}

${ }^{\mathrm{z}}$ 上 6 品種はスタンダードタイプ, 下 5 品種はスプレータイプ 覆輪で色差計による測定が困難な品種は花弁色調の測定值なし

$\mathrm{y}$ クロマティクネス指数が $\mathrm{a}^{*}>0, \mathrm{~b}^{*}>=0$ であったため, $\mathrm{h}^{\circ}=\left(\mathrm{ATAN}\left(\mathrm{b}^{*} / \mathrm{a}^{*}\right) / 6.2832\right) \times 360$ により算出 覆輪で色差計による測定 が困難な品種は花弁色調の測定は行わなかった

x 数表中の同一品種の同一アルファベット間に LSD 検定による 5\%水準の有意差なし また,アルファベットの記載のない箇所 では，試験区間に分散分析による5\%水準の有意差なし

w通常収穫区の出荷所要日数は記載した蕾径から出荷適期になるまでの日数とした 
第 3 表 収穫時の蕾径と出荷所要日数の回帰分析

\begin{tabular}{|c|c|c|c|c|}
\hline \multirow{2}{*}{ 品種名 } & \multirow{2}{*}{$\begin{array}{c}\text { 回帰式 } \\
(\mathrm{X}=\text { 収穫時の蕾径, } \mathrm{Y}=\text { 出荷所要日数 })\end{array}$} & \multicolumn{2}{|c|}{ 通常収穫区 } & \multirow{2}{*}{$\begin{array}{l}\text { BAA による出荷所要 } \\
\text { 日数の短縮 }(\text { 日 })^{z}\end{array}$} \\
\hline & & 蕾径（mm） & 出荷所要日数（日） & \\
\hline オペラ & $\mathrm{Y}=-1.225 \mathrm{X}+32.846 \quad\left(\mathrm{R}^{2}=0.9999\right)$ & 19.6 & 16.0 & -7.2 \\
\hline デルフィ & $\mathrm{Y}=-1.074 \mathrm{X}+27.565 \quad\left(\mathrm{R}^{2}=0.8794\right)$ & 16.4 & 16.6 & -6.6 \\
\hline プレジャー & $\mathrm{Y}=-1.532 \mathrm{X}+37.001 \quad\left(\mathrm{R}^{2}=0.9990\right)$ & 16.2 & 20.8 & -8.6 \\
\hline リカルド & $\mathrm{Y}=-0.523 \mathrm{X}+18.909 \quad\left(\mathrm{R}^{2}=0.3482\right)$ & 17.4 & 17.0 & -7.2 \\
\hline サレヤ & $\mathrm{Y}=-2.277 \mathrm{X}+49.024 \quad\left(\mathrm{R}^{2}=0.9806\right)$ & 17.2 & 18.6 & -8.7 \\
\hline ジュディス & $\mathrm{Y}=-1.097 \mathrm{X}+28.946 \quad\left(\mathrm{R}^{2}=0.9968\right)$ & 18.2 & 17.8 & -8.8 \\
\hline ホワイトバーバラ & $\mathrm{Y}=-3.419 \mathrm{X}+49.485 \quad\left(\mathrm{R}^{2}=0.9999\right)$ & 11.6 & 16.4 & -6.6 \\
\hline ライトピンクバーバラ & $\mathrm{Y}=-1.779 \mathrm{X}+31.116 \quad\left(\mathrm{R}^{2}=0.8795\right)$ & 12.4 & 16.2 & -7.1 \\
\hline ラベンダーテッシノ & $\mathrm{Y}=-2.538 \mathrm{X}+34.843\left(\mathrm{R}^{2}=0.9951\right)$ & 11.8 & 10.6 & -5.7 \\
\hline 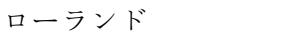 & $\mathrm{Y}=-2.163 \mathrm{X}+29.261 \quad\left(\mathrm{R}^{2}=0.9688\right)$ & 10.2 & 15.4 & -8.2 \\
\hline マエストロ & $\mathrm{Y}=-0.904 \mathrm{X}+19.694 \quad\left(\mathrm{R}^{2}=0.9999\right)$ & 14.4 & 17.6 & -10.9 \\
\hline
\end{tabular}

$\mathrm{z}$ (通常収穫区の調査開始時と同じ蕾径から予測した BAA 処理区の出荷所要日数）-(通常收穫区の出荷所要日数)

第 4 表 通常収穫およびBAA 処理カーネーションにおける満開時の花弁中糖質濃度

\begin{tabular}{|c|c|c|c|c|c|c|c|c|c|c|c|}
\hline \multirow[b]{2}{*}{ オペラ } & \multirow{2}{*}{$\begin{array}{l}\text { 処理 }^{y} \\
\text { 通常 } \\
\text { BAA }\end{array}$} & \multicolumn{2}{|c|}{$\begin{array}{c}\text { スクロース } \\
\left(\mathrm{mg} \cdot \mathrm{g}^{-1}\right)\end{array}$} & \multicolumn{2}{|c|}{$\begin{array}{c}\text { フルクトース } \\
\left(\mathrm{mg} \cdot \mathrm{g}^{-1}\right)\end{array}$} & \multicolumn{2}{|c|}{$\begin{array}{c}\text { グルコース } \\
\left(\mathrm{mg} \cdot \mathrm{g}^{-1}\right)\end{array}$} & \multicolumn{2}{|c|}{$\begin{array}{l}\text { ピニトール } \\
\left(\mathrm{mg} \cdot \mathrm{g}^{-1}\right)\end{array}$} & \multicolumn{2}{|c|}{$\begin{array}{c}\text { ミオイノシトール } \\
\left(\mathrm{mg} \cdot \mathrm{g}^{-1}\right)\end{array}$} \\
\hline & & $\begin{array}{l}1.3 \\
1.7\end{array}$ & $\mathrm{~ns}^{\mathrm{x}}$ & $\begin{array}{l}10.6 \\
10.9\end{array}$ & $\mathrm{~ns}$ & $\begin{array}{l}7.1 \\
5.9\end{array}$ & ns & $\begin{array}{l}5.5 \\
3.5\end{array}$ & $* *$ & $\begin{array}{l}0.4 \\
0.5\end{array}$ & ns \\
\hline デルフィ & $\begin{array}{l}\text { 通常 } \\
\text { BAA }\end{array}$ & $\begin{array}{l}1.8 \\
2.4\end{array}$ & $\mathrm{~ns}$ & $\begin{array}{l}10.9 \\
11.1\end{array}$ & $\mathrm{~ns}$ & $\begin{array}{l}5.6 \\
6.4\end{array}$ & ns & $\begin{array}{l}5.1 \\
3.6\end{array}$ & $\mathrm{~ns}$ & $\begin{array}{l}0.4 \\
0.4\end{array}$ & $\mathrm{~ns}$ \\
\hline プレジャー & $\begin{array}{l}\text { 通常 } \\
\text { BAA }\end{array}$ & $\begin{array}{l}1.1 \\
1.5\end{array}$ & ns & $\begin{array}{l}8.5 \\
9.1\end{array}$ & $\mathrm{~ns}$ & $\begin{array}{l}3.3 \\
3.2\end{array}$ & ns & $\begin{array}{l}6.8 \\
3.5\end{array}$ & $* *$ & $\begin{array}{l}0.7 \\
0.8\end{array}$ & $\mathrm{~ns}$ \\
\hline リカルド & $\begin{array}{l}\text { 通常 } \\
\text { BAA }\end{array}$ & $\begin{array}{l}1.9 \\
2.6\end{array}$ & * & $\begin{array}{l}16.5 \\
12.9\end{array}$ & * & $\begin{array}{l}8.0 \\
5.7\end{array}$ & $* *$ & $\begin{array}{l}7.3 \\
4.5\end{array}$ & $* *$ & $\begin{array}{l}1.0 \\
0.7\end{array}$ & $* *$ \\
\hline サレヤ & $\begin{array}{l}\text { 通常 } \\
\text { BAA }\end{array}$ & $\begin{array}{l}1.2 \\
1.3\end{array}$ & $\mathrm{~ns}$ & $\begin{array}{l}8.3 \\
8.5\end{array}$ & $\mathrm{~ns}$ & $\begin{array}{l}4.0 \\
3.7\end{array}$ & ns & $\begin{array}{l}3.7 \\
4.0\end{array}$ & ns & $\begin{array}{l}0.6 \\
0.7\end{array}$ & $\mathrm{~ns}$ \\
\hline ジュディス & $\begin{array}{l}\text { 通常 } \\
\text { BAA }\end{array}$ & $\begin{array}{l}1.9 \\
1.6\end{array}$ & $\mathrm{~ns}$ & $\begin{array}{l}6.5 \\
6.3\end{array}$ & ns & $\begin{array}{l}3.6 \\
3.1\end{array}$ & $\mathrm{~ns}$ & $\begin{array}{l}3.9 \\
3.2\end{array}$ & ns & $\begin{array}{l}1.0 \\
0.8\end{array}$ & ns \\
\hline ホワイトバーバラ & $\begin{array}{l}\text { 通常 } \\
\text { BAA }\end{array}$ & $\begin{array}{l}2.8 \\
4.3\end{array}$ & $* *$ & $\begin{array}{l}13.0 \\
16.7\end{array}$ & ns & $\begin{array}{l}8.6 \\
8.5\end{array}$ & $\mathrm{~ns}$ & $\begin{array}{l}6.0 \\
4.0\end{array}$ & ns & $\begin{array}{l}0.9 \\
0.6\end{array}$ & $\mathrm{~ns}$ \\
\hline ライトピンクバーバラ & $\begin{array}{l}\text { 通常 } \\
\text { BAA }\end{array}$ & $\begin{array}{l}1.8 \\
2.9\end{array}$ & $\mathrm{~ns}$ & $\begin{array}{l}10.7 \\
15.0\end{array}$ & $* *$ & $\begin{array}{l}6.7 \\
7.2\end{array}$ & ns & $\begin{array}{l}6.4 \\
3.6\end{array}$ & $* *$ & $\begin{array}{l}0.6 \\
0.4\end{array}$ & $*$ \\
\hline ラベンダーテッシノ & $\begin{array}{l}\text { 通常 } \\
\text { BAA }\end{array}$ & $\begin{array}{l}0.8 \\
2.5\end{array}$ & $\mathrm{~ns}$ & $\begin{array}{l}10.1 \\
27.9\end{array}$ & $* *$ & $\begin{array}{r}6.9 \\
18.1\end{array}$ & $*$ & $\begin{array}{l}3.6 \\
5.1\end{array}$ & ns & $\begin{array}{l}0.1 \\
1.2\end{array}$ & $* *$ \\
\hline ローランド & $\begin{array}{l}\text { 通常 } \\
\text { BAA }\end{array}$ & $\begin{array}{l}1.0 \\
2.3\end{array}$ & $* *$ & $\begin{array}{r}5.3 \\
12.0\end{array}$ & $* *$ & $\begin{array}{l}3.6 \\
8.0\end{array}$ & $* *$ & $\begin{array}{l}3.6 \\
2.0\end{array}$ & $* *$ & $\begin{array}{l}0.6 \\
0.6\end{array}$ & ns \\
\hline マエストロ & $\begin{array}{l}\text { 通常 } \\
\text { BAA }\end{array}$ & $\begin{array}{l}1.4 \\
3.4\end{array}$ & ns & $\begin{array}{l}10.7 \\
20.2\end{array}$ & $* *$ & $\begin{array}{r}6.9 \\
10.6\end{array}$ & $* *$ & $\begin{array}{l}5.1 \\
4.7\end{array}$ & ns & $\begin{array}{l}0.6 \\
0.6\end{array}$ & ns \\
\hline
\end{tabular}

z 上 6 品種はスタンダードタイプ, 下 5 品種はスプレータイプ

$\mathrm{y}$ 通常は通常収穫, BAA は蕾ステージ M で収穫し出荷適期まで BAA 処理

${ }^{\mathrm{x}} \mathrm{n}=3$ 表中の*および**は $\mathrm{t}$ 検定によりそれぞれ 5\%水準および $1 \%$ 水準で有意差あり $\mathrm{ns}$ は $5 \%$ 水準で有意差なし

\section{考 察}

筆者らはこれまでに，ピンク花色のスタンダードタイプ 品種である‘ノラ’を用いて，蕾開花促進（BAA）法に抒 ける採取ステージや温度（水口ら，2005a），光環境（水口 ら，2007a），処理液中のスクロース濃度（水口ら，2007b） を検討し,品質上の問題点とその対策を明らかにしてきた.
本報では, ‘ノラ’において切り花品質が良好であった処理 条件である温度 $25^{\circ} \mathrm{C}$, 光環境 $1 \mathrm{klx}$ で 12 時間日長, 処理液 のスクロース濃度 $5 \%$ に統一し,さむざまな品種について,

BAA 法への適応性を検討した。

BAA 法では，収穫ステージが若すぎると，未開花，障害 発生，花径の低下などの問題が生じることが明らかとなっ ている（水口ら，2005a）。そこでまず，障害が発生しやす 
第 5 表 品種ごとの BAA 処理に適した収穫時の蕾径および問題点

\begin{tabular}{|c|c|c|c|}
\hline 品種名 & $\begin{array}{l}\text { 障害発生の少ない } \\
\text { 最小蕾径 }(\mathrm{mm})^{\mathrm{z}}\end{array}$ & 品質上の問題点 & 解決策 \\
\hline オペラ & $\underline{14}$ & 花色発現不良 & 処理液組成 $y$ \\
\hline デルフィ & $\overline{16}$ & & \\
\hline プレジャー & 18 & & \\
\hline リカルド & $\underline{15}$ & 花色発現不良 & 処理液組成 \\
\hline サレヤ & $\overline{18}$ & & \\
\hline ジュディス & 15 & & \\
\hline ホワイトバーバラ & 11 & & \\
\hline ライトピンクバーバラ & 10 & & \\
\hline ラベンダーテッシノ & $\underline{8}$ & 花色発現不良 & 困難 \\
\hline ローランド & $\underline{8}$ & 花径と花持ち低下 & 困難 \\
\hline マエストロ & 10 & & \\
\hline
\end{tabular}

z下線の数値は障害発生はないものの, 品質低下が認められたことを示す

$\mathrm{y}$ 処理液中のスクロース濃度について検討の余地あり

いステージと発生しにくいステージを蕾径に基づいて調査 した（第 1 表）そその結果，蕾の収穫ステージが若いほぼ， がく割れ，花弁萎调，がくや葉の黄化などの障害が認めら れ，ある程度生育の進んだステージで収穫すると，ほとん ど障害は発生しなかった。このように, 本試験により障害 を回避するための収穫時の蕾径に基づくステージの範囲 を，品種ごとに明らかにすることができた.

次に, 障害発生の少ない蕾ステージの範囲で, 蕾径に基 づく L, M, S の 3 段階で, BAA 処理による出荷所要日数 扣よび切り花品質の変化を調査した (第 2 表). 出荷所要日 数は蕾径が小さい汪ど長くなるが，八ウス内でそのまま生 育する場合と比較すると, 出荷日が 5.7 日〜 10.9 日も早め られることが明らかとなった（第 3 表）.

わが国の切り花流通においては, 極めて高い品質が要求 されるため, BAA 処理により開花したカーネーションの切 り花品質について以下に詳細に考察する. 満開時の花の大 きさについてみると, ‘プレジャ一’抽び ‘ローランド” で花径の低下が認められた（第 2 表）. ‘プレジャー’では 処理開始時の蕾ステージを大きくすることで通常収穫区と 同等となったが, “ローランド’ではいずれの蕾径で処理し ても, 通常収穫区より $6 \mathrm{~mm}$ から $8 \mathrm{~mm}$ 程度小さく, 花径 を増大させることができなかった，蕾の開花ではシンク器 官である花弁に糖と水が急速に蓄積し, 細胞が急激に肥大 する（Kenisら，1985）ことから, スクロースを切り花に 処理することで, 花弁中の糖質濃度が高くなるとともに花 弁の展開が促進されることが明らかとなっている (Ichimura ら，1999）。実際, 処理液中のスクロース濃度を 高くすることで花弁の展開が促進され, 蕾切りカーネー ションの花径は大きくなる(水口ら, 2007b). しかし, ‘ロー ランド’の花弁中糖質濃度は, スクロース, グルコース, フルクトースともに通常収穫区より有意に高くなっていた (第 4 表). すなわち, 十分な量の糖質が供給できているに もかかわらず花弁の展開が不十分となったことから，より スクロース濃度の高い処理液を用いたとしても, 花径の向
上は期待できないと考学られる。な㸱, “ローランド’以外 の品種について，フプレジャー’の $\mathrm{S}$ サイズ収穫以外では, BAA 区の花径は通常収穫区と同等か有意に大きくなった ことから, 花のボリュームに関しては良好と判断できた.

満開時の花弁色調についてみると, ‘才ペラ’, ‘リカル ド’执よび ‘ラベンダーテッシノ’ では花色発現が抑制さ れた (第 2 表)。糖質がアントシアニンの生合成に関与して いることは, ペチュニア (Moscovici ら, 1996; Weiss・Halevy, 1989, 1991)，キンギョソウ（Sang ら，1991），およびトル コギキョウ（Kawabataら，1999）で明らかにされている. BAA 区の花弁中糖質濃度は， ‘才ペラ’ ではピニトールの みが通常収穫区より有意に低く、“リカルド”ではいずれの 糖質濃度も通常収穫区より有意に低く，逆に“ラベンダー テッシノ’ ではフルクトースとグルコースが有意に高く なっていた (第 4 表). 従って, ‘才ペラ’抽よび‘リカル ド’では糖質供給が不十分である可能性があり，今後，処 理液のスクロース濃度を高くすることによる花色発現の促 進について検討の余地がある. しかし, ‘ラベンダーテッシ ノ’では，十分な量の糖質が供給されているにもかかわら ず花色発現が不十分であったことから，処理液のスクロー ス濃度調節ではこれ以上の花色発現の向上は期待できない と考えられる.な拈, これら 3 品種以外では, BAA 区の花 色発現は通常収穫区と同等か有意に促進された.

‘プレジャー’，‘サレヤ’，‘ラベンダーテッシノ’抽よび “ローランド”では，S サイズ収穫に花持ち日数の低下が認 められた (第 2 表).それらのらち, ‘プレジャ一’, ‘サレ ヤ’拈よび ‘ラベンダーテッシノ’ では処理開始時の蕾サ

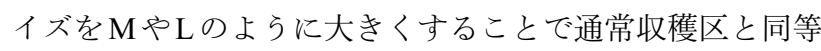
となったが, ‘ローランド’ではいずれの蕾ステージで処理 しても, 花持ちは通常収穫区よりも2.0〜 4.2 日短くなっ た. ‘ローランド’の BAA 区花弁中のスクロース，フルク トース执よびグルコース濃度は通常収穫区のものより有意 に高いことから，糖質は十分供給できて颃り，花持ち日数 の向上のためには前処理条件の改良が必要と考えられる. 
なお，これら以外の品種では，BAA 区の花持ちは通常收穫 区と同等か有意に延長できることが明らかとなった。

以上の結果から, BAA 処理に対する品種適応性を第 5 表 にまとめた。・ローランド’では満開時の花径と花持ちが低 下し，‘ラベンダーテッシノ’ では花色発現が不良となる. これらの品質低下は BAA 処理条件の改良では解決が困難 であることから, ‘ローランド’と“ラベンダーテッシノ’ はBAA 法に適さない品種と判断された. これら以外の品 種では, 処理に適した蕾径が品種によって異なるものの, 蕾径の最低基準を遵守することで，蕾の開花は促進でき， 障害の発生を注ぼ回避できる。 ‘オペラ’拈よび'リカル ド”では花色発現促進のために BAA 処理条件の改良が必 要と考兄られるが，その他の品種では今回の処理条件でも 通常収穫と同等かそれ以上の品質を確保できることが明ら かとなった。

このように，多くの品種で BAA 法を適用できることが 明らかとなった，生産現場で聞き取り調査したところ，技 術導入のための残された問題点として，処理に必要な資材 や装置等が市販されていない，寸なわち道具がないことが 挙げられている. 今後, 本格的にこの出荷調節技術を生産 現場に普及させるためには, 調合が容易な処理液や安価な 蕾開花促進処理装置の開発が不可欠である.

\section{摘 要}

蕾開花促進（BAA）法に，スタンダードタイプ 6 品種, スプレータイプ 5 品種を供試し, 温度 $25^{\circ} \mathrm{C}$, 相対湿度 75 $\%$, 光環境 $1 \mathrm{klx}$ で 12 時間日長，処理液のスクロース濃度 $5 \%$ の処理条件への適応性を評価した.いずれの品種でも収 穫時の蕾径が小さいほど，がく割れや花弁の萎调のような 障害発生が認められたが，ある程度成熟した蕾段階で処理 することにより，障害発生率は著しく低下した，障害発生 のほとんどない蕾ステージの範囲において, 蕾径に基づい て 3 段階で収穫し同様の処理を施したところ, 蕾径が大き いほど処理日数は短くなり, 同じ蕾径で比較すると通常収 穫より出荷日を 5.7 日〜 10.9 日短縮できた. プレジャーで は蕾径 $15.2 \mathrm{~mm}$ 収穫で通常収穫より花径が小さく花持ちが 短くなったが， $18.4 \mathrm{~mm}$ 以上で収穫すると通常收穫と同等 となった. しかし，‘ラベンダーテッシノ’の花色発現拉よ び“ローランド’の花径と花持ちはいずれのステージで処 理しても解決できず, BAA 処理条件の調節による改善も困 難と考学られ，BAA 法には適さない品種と判断できた。

\section{引用文献}

Cywińska, S. K., R. M. Rudnicki and D. Goszczyńska. 1978. The effect of exogenous growth regulators in opening tight carnation buds. Sci. Hort. 9: 155-165.

愛媛県農林水産部技術指導課. 1999. カーネーション作型 冬切り. p. 26. 愛媛県農林水産部技術指導課編. 愛媛 県施肥基準 (平成 12 年度版).
Goszczyńska, D. and R. M. Rudnicki. 1983. Long-term cool storage of bud-cut carnations. Acta Hort. 141: 203-212.

Ichimura, K., S. Ueyama and R. Goto. 1999. Possible roles of soluble carbohydrate constituents in cut rose flowers. J. Japan. Soc. Hort. Sci. 68: 534-539.

Kawabata, S., Y. Kusuhara, Y. Li and R. Sakiyama. 1999. The regulation of anthocyanin biosynthesis in Eustoma grandiflorum under low light conditions. J. Japan. Soc. Hort. Sci. 68: 519-526.

Kenis, J. D., S. T. Silvente and V. S. Trippi. 1985. Nitrogen metabolism and senescence-associated changes during growth of carnation flowers. Physiol. Plant. 65: 455-459.

Kofranek, A. M., D. S. Farnham, E. C. Maxie and J. Kubota. 1972. Long term storage of carnation buds. Flor. Rev. 151: 29-30.

小山佳彦・宇田 明. 1994a. カーネーションのつぼみ開花 および品質に及ぼす温度, 照度, ショ糖濃度の影響. 園学雑. 63: 203-209.

小山佳彦・宇田 明. 1994b. つ济み切りカーネーションの 貯蔵沶よび開花法. 園学雑. 63:211-217.

McGuire, R. G. 1992. Reporting of objective color measurements. HortScience 27: 1254-1255.

水口 聡・市村一雄・久松 完・腰岡政二. 2007b. スク ロース処理が蕾切りカーネーションの切り花品質扎よ び糖質濃度に及ぼす影響. 園学研. 6: 591-596.

Minakuchi, S., H. Watanabe and T. Kawasaki. 2004. Actual states of harvesting and shipping of carnations, and possibility of shipping regulation by bud anthesis acceleration (BAA). The Society of Agricultural Structures, Japan (SASJ). 35: 165-172.

水口 聡・渡辺 久・川崎哲郎. 2005a. カーネーションの 蕾開花促進に拈ける採取ステージおよび温度が出荷ま での日数や切り花品質に及ぼす影響. 農業施設. 36 : 153-159.

水口 聡・渡辺 久・川崎哲郎. 2005b. チ才硫酸銀錯塩が 蕾開花促進カーネーションの花持ちに及ぼす影響扣よ び蕾開花促進処理液中の硝酸銀の必要性. 近畿中国四 国農研. 6: 30-34.

水口 聡・渡辺 久・川崎哲郎. 2007a. カーネーションの 蕾開花促進における明暗周期が開花速度および切り花 品質に及ぼす影響。農業施設. 37: 193-198.

Moscovici, S., D. Moalem-Beno and D. Weiss. 1996. Leafmediated light responses in petunia flowers. Plant Physiol. 110: $1275-1282$.

Rudnicki, R. M., D. Goszczyńska and R. Tomasz. 1989. Bud opening and long term storage of spray carnations. Acta Hort. 261: 265-270.

Sang, C. K., Y. S. Choi and H. Y. Kim. 1991. Effects of light, sucrose and growth regulators on the coloration of cut 
snapdragon flower: I. Effects of light intensity and sucrose. J. Korea. Soc. Hort. Sci. 32: 130-136 (in Korean with English abstract).

Weiss, D. and A. H. Halevy. 1989. Stamens and gibberellin in the regulation of corolla pigmentation and growth in Petunia hybrida. Planta 179: 89-96.

Weiss, D. and A. H. Halevy. 1991. The role of light reactions in the regulation of anthocyanin synthesis in Petunia corollas. Physiol. Plant. 81: 127-133. 